\title{
Substrate autoregulation of glucose transport: hexose 6-phosphate mediates the cellular distribution of glucose transporters
}

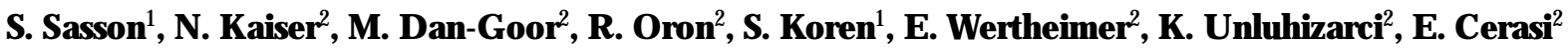 \\ ${ }^{1}$ D epartment of Pharmacology, H ebrew U niversity of Jerusalem Faculty of M edicine, School of Pharmacy, Jerusalem, I srael \\ ${ }^{2}$ D epartment of $\mathrm{E}$ ndocrinology and M etabolism, The H ebrew U niversity-H adassah M edical Center, J Jerusalem, I srael
}

Summary Exposure of rat skeletal muscle and skeletal muscle cell lines to high glucose levels results in a time- and dose-dependent reduction of the rate of hexose uptake, paralleled by a reduction in the plasma membrane density of glucose transporters. The mechanism of this process was investigated in cultured L 8 myocytes. Low concentrations (0.5$2.0 \mathrm{mmol} / \mathrm{l}$ ) of deoxyglucose mimicked the downregulatory action of $20 \mathrm{mmol} / \mathrm{l}$ glucose both regarding the time-course and magnitude of the effect, but in an irreversible manner. A dose-dependent relationship between intracellular accumulation of deoxyglucose 6-phosphate and the magnitude of the downregulatory response was observed. D epletion of intracelIular deoxyglucose 6-phosphate restored the rate of hexose transport to the control level. The reduction of hexose transport activity by deoxyglucose occurred independently of A TP depletion which by itself produced the opposite effect. The effects of deoxyglucose and high glucose on hexose transport were associated with reduced transport maximal velocity and G L U T 1 transporter abundance in the plasma membranes of myocytes, as assessed by cell surface biotinylation. The reduction of myocyte GLUT 1 mR N A content, observed after exposure to high glucose, did not accompany the transport downregulatory action of deoxyglucose. We suggest that hexose 6-phosphate is the mediator of the downregulatory signal for subcellular redistribution of G L UT1 in $L 8$ myocytes. The signal responsible for reducing the GLUT1 mRNA level may be related to glucose metabolites downstream of the hexokinase reaction. [D iabetologia (1997) 40: 30-39]

Keywords Glucose transporters, GLUT1, glucose, deoxyglucose, deoxyglucose 6-phosphate, glucose 6phosphate, hexose 6-phosphate, skeletal muscle, myocyte, diabetes mellitus.
The hexose transport system in skel etal muscle is subject to complex regulation. We have previously shown that hexose uptake and utilisation in cultured rat myocytes and myotubes and in isolated rat soleus

R eceived: 1 A ugust 1996 and in revised form: 17 O ctober 1996

Corresponding author: S. Sasson, Ph.D., D epartment of Pharmacology, School of M edicine, H ebrew U niversity of J erusalem. P. O.B ox 12272, Jerusalem 91120, I srael

A bbreviations: A IB, $\alpha$-aminoisobutyric acid; BSA, bovine serum albumin; $C B$, cytochalasin $B$; dG Ic, 2-deoxy-D-glucose; dG Ic-6-P, 2-deoxy-D-glucose 6-phosphate; DNP, dinitrophenol; D ME M , D ulbecco's modified E agle's medium; FCS, fetal calf serum; M eG Ic, 3-O -methylglucose; NH S-L C biotin, sulphosuccinimidyl 6-(biotinamido) hexanoate; PMSF, phenylmethylsulfonyl fluoride; PBS, phosphate buffered saline. muscles in vitro are dependent on the D-glucose concentration to which the cells and muscles are pre-exposed [1-5]. Similar effects of glucose withdrawal and refeeding have been reported in cultured $L 6$ [6] and $\mathrm{BC} 3 \mathrm{H} 1$ skeletal muscle cells [7] as well as in human skeletal muscle [8]. The maximal velocity of hexose transport $\left(\mathrm{V}_{\max }\right)$ was reduced in $\mathrm{L} 8$ skeletal muscle cells exposed to increasing glucose concentrations (0.5-20.0 $\mathrm{mmol} / \mathrm{l})$ in a concentration-dependent manner, while the affinity $\left(K_{m}\right)$ was unaffected [2]. Cytochalasin $B(C B)$ binding and G LU T 1 Western blotting of enriched plasma- and microsomal-membrane fractions revealed that high glucose concentrations modulated the subcellular distribution of G LU T1, reducing their number at the plasma membrane of the cell [1]. Similar autoregulatory effects of glucose 
were found in a variety of cells (for a review see [9]). In addition, high glucose levels induced a time-dependent reduction in the G LUTI mR NA abundance in L 8 myocytes [5] and other cells studied [9]. It has been proposed that the downregulation of glucose transport and utilisation in skeletal muscle via this autoregulatory mechanism may be important for the induction of reduced peripheral glucose utilisation and insulin resistance in diabetes mellitus [10-12].

The nature of the intracellular signal that operates the downregulation of glucose transport is unknown. G lucose is rapidly metabolised in muscle cells; any of its metabolites responsible for initiating the downregulation of transport may be expected to be short-lived and therefore difficult to identify. We therefore chose to use the glucose analogue 2-deoxy-D-glucose ( $d G \mid c)$ to study the modulation of the hexose transport system of $L 8$ muscle cells. This analogue is transported by glucose transporters and phosphorylated by hexokinase, but it is not metabolised further. The findings of the present report suggest that hexose 6-phosphate interacts with the intracellular sensing mechanisms for the downregulation of glucose transport.

\section{Materials and methods}

M aterials. 2-[1, 2- $\left.{ }^{3} \mathrm{H}\right] \mathrm{dG}$ Ic $(40 \mathrm{Ci} / \mathrm{mmol}$ ) was purchased from A merican R adiolabelled Chemicals (St. Louis, M o., USA). [M ethyl- ${ }^{3} \mathrm{H}$ ]aminoisobutyric acid $(23.5 \mathrm{Ci} / \mathrm{mmol}), 3-0-[\mathrm{me}-$ thyl- ${ }^{3} \mathrm{H}$ ]glucose $(79 \mathrm{Ci} / \mathrm{mmol}),\left[\mathrm{U}-{ }^{14} \mathrm{C}\right]$ sucrose $(442 \mathrm{mCi} /$ $\mathrm{mmol})$, and [32P]-deoxycytidine $5^{\prime}$-triphosphate $(\sim 3000 \mathrm{Ci} /$ mmol) were from Dupont-New England Nuclear (Boston, M ass., USA ). R ediprime DNA labelling system and Rapidhyb hybridisation buffer were obtained from the R adiochemical Centre (A mersham, UK). A ntipain, aprotinin, bovine serum albumin (BSA), CB, dG Ic, glycine, luciferine-luciferase kit for A TP determination, 3-O -methylglucose ( $M$ eG IC), phenylmethylsulphonyl fluoride (PM SF), saponin and streptavidin-agarose beads were obtained from Sigma Chemicals (St. Louis, M o., USA). D -glucose was from Merck (D armstadt, Germany). Sulphosuccinimidyl 6-(biotinamido) hexanoate (NHS-L C biotin) was from Pierce (R ockford, III., U SA ). L eupeptin, $\alpha$-macroglobulin, and positively charged nylon membranes were obtained from Boehringer $M$ annheim ( $M$ annheim, G ermany). D owex-1-chloride (4\% cross-link) was from D owex Chemical Co., obtained through Sigma Chemicals. M icroSpin columns for purification of labelled probes were from Pharmacia Biotechnology (U ppsala, Sweden). Triton X-100 was obtained from BDH Chemicals (Poole, UK). Waymouth medium and fetal calf serum (FCS) were from Biological Industries (K ibbutz Beth-Haemek, Israel). Glucose-free Dulbecco's modified Eagle's medium (DMEM) was purchased from Gibco Laboratories (Grand Island, N.Y., USA). All other chemicals and reagents were reagent or molecular biology grade.

Cells and culture conditions. M yocytes of the $L 8$ cell line were kindly donated by Dr. D. Yaffe (Weizmann Institute of Science, R ehovot, I srael). The cells were grown as previously described [2]. The glucose concentration of FCS was $\sim 5 \mathrm{mmol} / \mathrm{l}$, consequently glucose-free incubates in reality contained $\sim 1.0 \mathrm{mmol}$ glucose/l.
M easurement of $\mathrm{dG} / \mathrm{C}$ and $\alpha$-aminoisobutyric acid (AIB) uptake. The $L 8$ culture plates were rinsed five times with $2 \mathrm{ml}$ PBS (in mmol/l: $137 \mathrm{NaCl}, 2.7 \mathrm{KCl}, 9.6 \mathrm{Na}_{2} \mathrm{HPO}_{4}, 1.5$ $\mathrm{KH}_{2} \mathrm{PO}_{4}, 0.5 \mathrm{M} \mathrm{gCl}_{2}, \mathrm{pH} 7.4$ ) at room temperature; thereafter, $1 \mathrm{ml} \mathrm{PBS}$ containing $0.1 \mathrm{mmol} / / \mathrm{dG} \mathrm{Ic}, 0.5 \mu \mathrm{Ci}\left[{ }^{3} \mathrm{H}\right] \mathrm{dG} / \mathrm{c}$ and $0.25 \mu \mathrm{Ci}\left[{ }^{14} \mathrm{C}\right.$ ] sucrose was added to triplicate plates, and incubated for $5 \mathrm{~min}$ at room temperature. The uptake of $\left[{ }^{3} \mathrm{H}\right] \mathrm{dG} / \mathrm{C}$ into L 8 myocytes was linear up to 15 min [2]. CB-noninhibitable dG Ic uptake was less than $5 \%$ of total uptake. The uptake of dG Ic was calculated after correction for the extracellular dG Ic as determined with $\left[{ }^{14} \mathrm{C}\right]$ sucrose.

The uptake of A I B was measured similarly, using $0.1 \mathrm{mmol} / \mathrm{l}$ $\mathrm{A} I \mathrm{~B}, 1.0 \mu \mathrm{Ci}\left[{ }^{3} \mathrm{H}\right] \mathrm{A} \mathrm{IB}$ and $0.25 \mu \mathrm{Ci}\left[{ }^{14} \mathrm{C}\right]$ sucrose. The incubation was carried out for $5 \mathrm{~min}$ at room temperature.

M easurement of M eG Ic uptake. The cultures were rinsed as described above and incubated at room temperature for $10 \mathrm{~s}$ with $1 \mathrm{ml}$ PBS containing $0.1 \mathrm{mmol} / \mathrm{l} \mathrm{MeG} \mathrm{C}, 2.0 \mu \mathrm{Ci}\left[{ }^{3} \mathrm{H}\right.$ ]M eG IC and $0.25 \mu \mathrm{Ci}\left[{ }^{14} \mathrm{C}\right]$ sucrose. The uptake was terminated by the addition of $10 \mu \mathrm{mol} / \mathrm{l} \mathrm{CB}$ for an additional $10 \mathrm{~s}$, followed by five washes with $2 \mathrm{ml}$ ice-cold PBS. O ne set of control plates received PBS containing $10 \mu \mathrm{mol} / / \mathrm{CB}$ one min before the addition of $M$ eG IC, and served to determine the $C B$-noninhibitable M eG Ic transport (10-20\% of total uptake). CB-inhibitable M eG Ic uptake was calculated after correction for the $\mathrm{CB}$-noninhibitable uptake and extracellular $\left[{ }^{3} \mathrm{H}\right] \mathrm{M}$ eG $\mathrm{IC}$, as determined with $\left[{ }^{14} \mathrm{C}\right]$ sucrose.

M easurement of intracellular free and phosphorylated dG Ic. A modification of the method of Tsuboi and Petricciani was used [13]. M yocytes grown to confluency were incubated with $5 \mathrm{ml}$ PBS containing dG Ic at the desired concentrations and $10 \mu \mathrm{Ci}\left[{ }^{3} \mathrm{H}\right] \mathrm{dG} \mathrm{Ic}$. The incubation was terminated by five rapid washes with $10 \mathrm{ml}$ ice-cold PBS containing $10 \mu \mathrm{mol} / \mathrm{l} C B$. The cells were then treated with $4 \mathrm{ml}$ of $0.2 \%$ (v/v) Triton $X-100$ in water at room temperature, collected and treated further with $3 \mathrm{ml}$ chloroform. A fter centrifugation 1-ml aliquots of the water phase were passed through ion-exchange columns (D owex-1-chloride). Free dG Ic was eluted with $10 \mathrm{ml}$ water, phosphorylated dG Ic with $10 \mathrm{ml} 4 \mathrm{~N} \mathrm{HCl}$. R ecovery was above $90 \%$. Under all incubation conditions free dG Ic accounted for only $5-10 \%$ of the total radioactivity eluted.

Cell surface biotinylation. Surface biotinylation of $L 8$ myocytes was adapted from Shetty et al. [14] and Levy-Toledano et al. [15]. L 8 myocytes in $100 \mathrm{~mm}$ culture plates were washed with ice-cold PBS and incubated with $0.5 \mathrm{mg} / \mathrm{ml} \mathrm{NHS}-\mathrm{LC}$ biotin in PBS for $30 \mathrm{~min}$ at $4{ }^{\circ} \mathrm{C}$. The reaction was stopped by rinsing the plates three times with $15 \mathrm{mmol} / \mathrm{l}$ glycine in ice-cold PBS. The cells were then collected and solubilised for $30 \mathrm{~min}$ on ice in $1 \mathrm{ml}$ solubilisation buffer $(150 \mathrm{mmol} / \mathrm{l} \mathrm{NaCl}, 50 \mathrm{mmol} / \mathrm{l} \mathrm{H} \mathrm{e}-$ pes, $\mathrm{pH} 7.4,1 \%$ (v/v) Triton X-100, $2 \mathrm{mmol} / \mathrm{l} \mathrm{PM} \mathrm{SF}, 2 \mu \mathrm{g} / \mathrm{ml}$ aprotinin, $0.1 \mathrm{mmol} / \mathrm{l}$ antipain, $0.2 \mathrm{mmol} / /$ leupeptin and 0.5 $\mathrm{U} / \mathrm{ml} \alpha$-macroglobulin). The supernatant was separated by a 2-min centrifugation in an Eppendorf centrifuge and mixed with $50 \mu \mathrm{l}$ streptavidin-agarose beads ( $1 \mathrm{mg}$ streptavidin/ $1 \mathrm{ml}$ gel in solubilisation buffer containing $0.1 \mathrm{mmol} / \mathrm{l} \mathrm{PM} \mathrm{SF}$ ). The suspension was gently mixed for $30 \mathrm{~min}$ at $4{ }^{\circ} \mathrm{C}$ and the beads sedimented by centrifugation. The bead pellet was washed with $150 \mathrm{mmol} / / \mathrm{NaCl}, 10 \mathrm{mmol} / \mathrm{l}$ Tris, $\mathrm{pH}$ 7.0, containing $2 \mathrm{mmol} / \mathrm{PMSF}$ and $0.2 \mathrm{mmol} / \mathrm{l}$ leupeptin. The final pellet was resuspended in $120 \mu \mathrm{l} \mathrm{L}$ aemmli buffer (1.2-fold concentrated, without bromophenol blue [16]) and incubated for $30 \mathrm{~min}$ at $65^{\circ} \mathrm{C}$. The supernatant was separated from the beads by centrifugation, collected and kept at $-70^{\circ} \mathrm{C}$ until used.

Western blot analysis. Protein content in the streptavidin-purified membrane preparations was determined by the Bio-R ad 
DC Protein assay (Bio-Rad Laboratories, Hercules, Calif., USA ), using BSA standard dissolved in the same buffer of the membrane preparation. Western blots were performed as described earlier [5], with specific rabbit antiserum against synthetic rat G L U T $1 \mathrm{~N}$-terminus ( 1:500 dilution).

Cell permeabilisation. Permeabilisation of $L 8$ myocytes was performed according to Johnson et al. [17]. In short, cultured cells were chilled to $4^{\circ} \mathrm{C}$ and treated with permeabilisation buffer $(20 \mathrm{mmol} / \mathrm{l}$ HEPES, pH 7.4, $10 \mathrm{mmol} / \mathrm{l}$ EGTA, $150 \mathrm{mmol} / \mathrm{l} \mathrm{KCl}, 5 \mathrm{mmol} / \mathrm{l}$ oxalic acid-dipotassium salt, $6 \mathrm{mmol} / \mathrm{l} \mathrm{ATP}$ and $50 \mu \mathrm{g} / \mathrm{ml}$ saponin) for $10 \mathrm{~min}$ in an ice bath. The cells were then washed gently and incubated with ice-cold PB S for a 20 min recovery (resealing) period followed by 2 min incubation with PBS at room temperature. This step was repeated with $\mathrm{PBS}$ at $37^{\circ} \mathrm{C}$ after which the cells were incubated with DMEM with the specified additions.

RNA isolation and Northern blot analysis. Total cellular R N A was isolated from 2-3 confluent $100-\mathrm{mm}$ plates by the R N A zol method (Cinna/B iotex, Friendswood, Texas, U SA ) according to the manufacturer's instructions. Twenty microgram aliquots were separated by electrophoresis on $1 \%$ agarose-formaldehyde gels containing $0.04 \%$ ethidium bromide, RNA was transferred to nylon membranes and prehybridised for $3 \mathrm{~h}$ at $65^{\circ} \mathrm{C}$ in $\mathrm{R}$ apid-hyb hybridisation buffer, followed by hybridisation to random-primed ${ }^{32} \mathrm{P}$-labelled $\mathrm{CDNA}$ probes of rat GLUT1 [5] and mouse $\alpha_{1}$ tubulin ( $1.1 \mathrm{~kb}$ fragment obtained from Dr. P. Dobner, U niversity of Massachusetts Medical School, B oston, M ass., U SA ), purified by M icroSpin columns.

ATP determination. The myocytes were washed eight times with PBS, collected in hot $\left(90^{\circ} \mathrm{C}\right)$ double-distilled water and boiled for $10 \mathrm{~min}$. The resulting lysate was taken for A TP determination by the luciferine-luciferase method [18] using an LK B -Wallac luminator (Bromma, Sweden).

G lucose determination. Glucose in aliquots of incubation media was determined by the glucose oxidase method using a B eckman G lucose A nalyzer (Fullerton, Calif., U SA ).

Statistical analyses were performed by Student's t-test. R esults are expressed as mean \pm SE M. A bsence of bars in figures indicates that the SE M is smaller than the symbol.

\section{Results}

Effect of dG Ic on hexose transport in L 8 myocytes. The effect of dGIc was investigated in upregulated L 8 myocytes (preincubated for $20 \mathrm{~h}$ with DMEM containing $2.0 \mathrm{mmol} / \mathrm{l}$ glucose). The cells were washed and received glucose-free DMEM supplemented with $2.0 \mathrm{mmol} / \mathrm{l} \mathrm{dG} \mathrm{Ic} \mathrm{or} 20.0 \mathrm{mmol} / \mathrm{l}$ glucose, and the rate of $\left[{ }^{3} \mathrm{H}\right] \mathrm{dG}$ Ic uptake was determined at the indicated times. Shortly after its introduction $\mathrm{dG} / \mathrm{c}$ initiated a downregulatory process of hexose transport, with a half maximal effect at $2.2 \mathrm{~h}$ (Fig. 1). This dG Ic-induced downregulation was similar to the effect induced by $20.0 \mathrm{mmol} / \mathrm{l}$ glucose. The effect of dG Ic was specific: while both $20.0 \mathrm{mmol} / \mathrm{l}$ glucose and $2.0 \mathrm{mmol} / \mathrm{l} \mathrm{dG}$ Ic elicited downregulation of hexose uptake, neither affected the uptake of AIB in L 8 myocytes (Table 1).

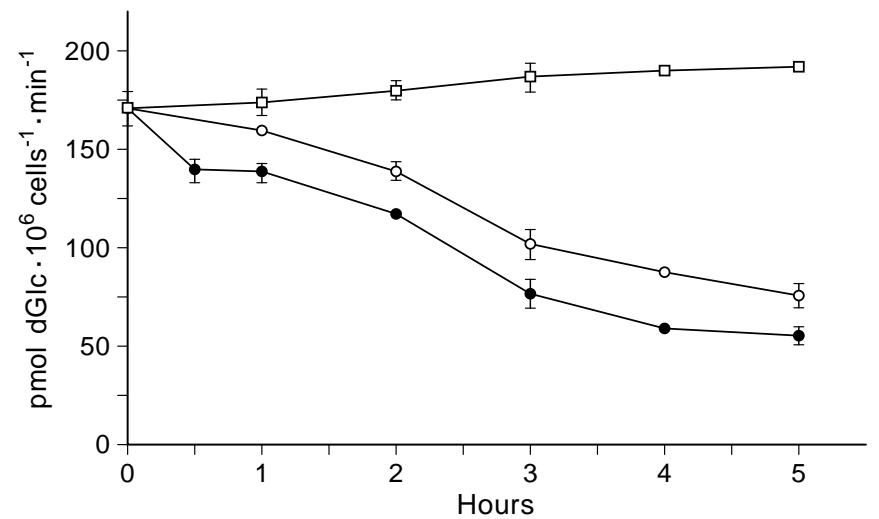

Fig. 1. E ffect of dG Ic on hexose transport. L 8 myocytes were preincubated in DMEM containing $2.0 \mathrm{mmol} / \mathrm{l}$ glucose for $20 \mathrm{~h}$, cells were then washed and received fresh DMEM containing $2.0 \mathrm{mmol} / \mathrm{l}$ glucose $(\square), 20.0 \mathrm{mmol} / \mathrm{l}$ glucose $(\bigcirc)$, or $2.0 \mathrm{mmol} / \mathrm{l} \mathrm{dG} \mathrm{Ic} \mathrm{(O).} \mathrm{A} \mathrm{t} \mathrm{the} \mathrm{indicated} \mathrm{times} \mathrm{the} \mathrm{cells} \mathrm{were} \mathrm{wa-}$ shed extensively and the uptake of $\left[{ }^{3} \mathrm{H}\right] \mathrm{dG}$ Ic was determined as described under Experimental Procedures. M ean $\pm S E M$, $\mathrm{n}=3$

Table 1. E ffect of dG IC on A IB uptake

\begin{tabular}{lcl}
\hline Treatment & $\begin{array}{l}\mathrm{dG} \mathrm{Ic} \mathrm{uptake} \\
\mathrm{pmol} \cdot 10^{6} \mathrm{cells}^{-1} \cdot \\
\mathrm{min}^{-1}\end{array}$ & $\begin{array}{l}\text { A IB uptake } \\
\mathrm{pmol} \cdot 10^{6} \mathrm{cells}^{-1} . \\
\mathrm{min}^{-1}\end{array}$ \\
\hline Control & $126.0 \pm 6.7$ & $34.6 \pm 4.2$ \\
$\rightarrow 20.0 \mathrm{mmol} / \mathrm{l}$ glucose & $77.8 \pm 2.3^{\mathrm{a}}$ & $35.8 \pm 4.2$ \\
$\rightarrow 2.0 \mathrm{mmol} / \mathrm{dG} \mathrm{Ic}$ & $68.6 \pm 3.1^{\mathrm{a}}$ & $30.2 \pm 3.8$
\end{tabular}

L 8 myocytes were incubated for $20 \mathrm{~h}$ at $2.0 \mathrm{mmol} / \mathrm{l}$ glucose (control), then washed and switched to $20.0 \mathrm{mmol} / \mathrm{l}$ glucose or $2.0 \mathrm{mmol} / \mathrm{l} \mathrm{dG} \mathrm{Ic} \mathrm{for} \mathrm{additional} 5 \mathrm{~h}$. [ $\left.{ }^{3} \mathrm{H}\right] \mathrm{dG} / \mathrm{C}$ and $\left[{ }^{3} \mathrm{H}\right] \mathrm{A} \mathrm{IB}$ uptake assays were performed as described in Methods. $\mathrm{M}$ ean $\pm \mathrm{SE} M, n=3$. ${ }^{\mathrm{a}} \mathrm{p}<0.05$ compared to control

To determine whether the downregulatory effect of dG Ic was restricted to the transport mechanism or combined with changes in the hexokinase reaction we compared the uptake rates of $\left[{ }^{3} \mathrm{H}\right] \mathrm{dG} / \mathrm{c}$ and $\left[{ }^{3} \mathrm{H}\right] \mathrm{M}$ eG Ic in myocytes treated with dG Ic or high glucose (Table 2). The uptake rates of both glucose analogues were reduced in a comparable manner, indicating that both agents modulated the transport step rather than the hexokinase reaction.

The effect of dG Ic was dose-dependent (Fig.2): cells maintained for $20 \mathrm{~h}$ at 2.0 or $20.0 \mathrm{mmol} / \mathrm{l}$ glucose received fresh medium containing increasing concentrations of dG lc for $5 \mathrm{~h}$; upregulated myocytes (pretreated with $2.0 \mathrm{mmol} / \mathrm{l}$ glucose) reduced the rate of hexose transport dose-dependently up to $7.0 \mathrm{mmol} / \mathrm{l}$ dG Ic, while at higher dG Ic concentrations an escape from the downregulatory response was observed. In downregulated myocytes (pretreated with $20.0 \mathrm{mmol} /$ I glucose) the rate of hexose transport remained low with dG Ic up to $7 \mathrm{mmol} / \mathrm{l}$, while higher dG Ic concentrations increased the rate of hexose transport.

In contrast to the reversible effect of glucose, the dGIc-induced downregulation of hexose transport 
Table 2. $R$ ates of $\left[{ }^{3} \mathrm{H}\right] \mathrm{dG} / \mathrm{C}$ and $\left[{ }^{3} \mathrm{H}\right] \mathrm{M}$ eG Ic uptake

\begin{tabular}{|c|c|c|c|c|}
\hline \multirow[t]{2}{*}{ Treatment } & \multicolumn{2}{|l|}{ M eG Ic uptake } & \multicolumn{2}{|l|}{ dG Ic uptake } \\
\hline & $\mathrm{pmol} \cdot 10^{6} \mathrm{cells}^{-1} \cdot 10 \mathrm{~s}^{-1}$ & $(\%)$ & $\mathrm{pmol} \cdot 10^{6} \mathrm{cells}^{-1} \cdot \mathrm{min}^{-1}$ & $(\%)$ \\
\hline $\begin{array}{l}\text { Control } \\
\rightarrow 2.0 \mathrm{mmol} / \mathrm{l} \text { glucose } \\
\rightarrow 20.0 \mathrm{mmol} / / \mathrm{glucose} \\
\rightarrow 2.0 \mathrm{mmol} / \mathrm{lgG} \mathrm{Ic}\end{array}$ & $\begin{array}{r}15.1 \pm 1.4 \\
14.1 \pm 1.0 \\
4.7 \pm 0.4^{\mathrm{a}} \\
4.4 \pm 0.5^{\mathrm{a}}\end{array}$ & $\begin{array}{r}100 \\
93.4 \pm 6.6 \\
31.1 \pm 2.6 \\
29.1 \pm 3.3\end{array}$ & $\begin{array}{c}202.6 \pm 2.7 \\
194.4 \pm 34.6 \\
76.5 \pm 20.1^{\mathrm{a}} \\
97.3 \pm 8.6^{\mathrm{a}}\end{array}$ & $\begin{array}{l}100 \\
96.0 \pm 17.1 \\
37.8 \pm 9.9 \\
48.0 \pm 4.2\end{array}$ \\
\hline
\end{tabular}

L 8 myocytes were incubated with DMEM supplemented with $2.0 \mathrm{mmol} / \mathrm{l}$ glucose for $20 \mathrm{~h}$ (control). The cells were then washed and received fresh medium with the indicated hexose

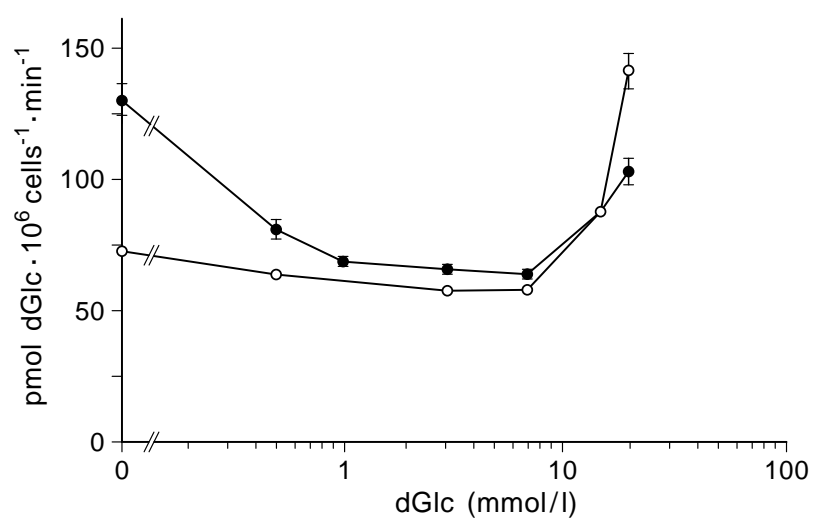

Fig. 2. dGIC dose-response curve. L 8 myocytes were preincubated for $20 \mathrm{~h}$ with DM EM containing $2.0(\mathrm{O})$ or $20.0 \mathrm{mmol} / \mathrm{l}$ glucose $(O)$, then washed and incubated with fresh DMEM containing increasing concentrations of dG Ic $(0.5-20.0 \mathrm{mmol} /$ I) for additional $5 \mathrm{~h}$, after which the cells were washed extensively and the rate of $\left[{ }^{3} \mathrm{H}\right] \mathrm{dG} I \mathrm{C}$ was measured. M ean $\pm \mathrm{SEM}$, $\mathrm{n}=3$

was long-lasting. Figure $3 \mathrm{~A}$ shows that exposure of the cells to $20.0 \mathrm{mmol} / \mathrm{l}$ glucose for $2 \mathrm{~h}$ resulted in $21 \%$ reduction in the rate of hexose transport; change of the incubate to $2.0 \mathrm{mmol} / \mathrm{l}$ glucose at this time restored the rate of uptake to the initial level in a typical upregulatory response. However, washing the cells $30 \mathrm{~min}$ or $2 \mathrm{~h}$ after exposure to $2.0 \mathrm{mmol} / \mathrm{l}$ $\mathrm{dG} / \mathrm{c}$, and maintaining them at $2.0 \mathrm{mmol} / \mathrm{l}$ glucose, did not prevent the progression of the downregulatory response, which reached a similar low level of uptake as cultures exposed continuously to $2.0 \mathrm{mmol} / \mathrm{l}$ dG Ic (Fig. 3B ). These data suggest that the downregulatory response initiated by $\mathrm{dG} / \mathrm{C}$ is dependent upon the accumulation of a long-lasting intracellular signal.

R elationship between intracellular content of 2-deoxyD-glucose 6-phosphate (dG Ic-6-P) and downregulation of hexose transport. Since incubation of myocytes with $\mathrm{dG} / \mathrm{C}$ results in intracellular accumulation of dG Ic-6-P, we measured its content and correlated it to the degree of downregulation of transport. M yocytes were exposed continuously to $2.0 \mathrm{mmol} / \mathrm{l} \mathrm{dG} \mathrm{Ic}$, and the rate of hexose uptake and the cellular dG Ic6-P content were determined at various times up to additions and incubated for $5 \mathrm{~h}$, washed again and taken for the standard $\left[{ }^{3} \mathrm{H}\right] \mathrm{dG}$ Ic or $\left[{ }^{3} \mathrm{H}\right] \mathrm{M}$ eG Ic uptake assays as described in M ethods. M ean $\pm \mathrm{SE} M, n=3 .{ }^{\mathrm{a}} \mathrm{p}<0.05$ compared to control

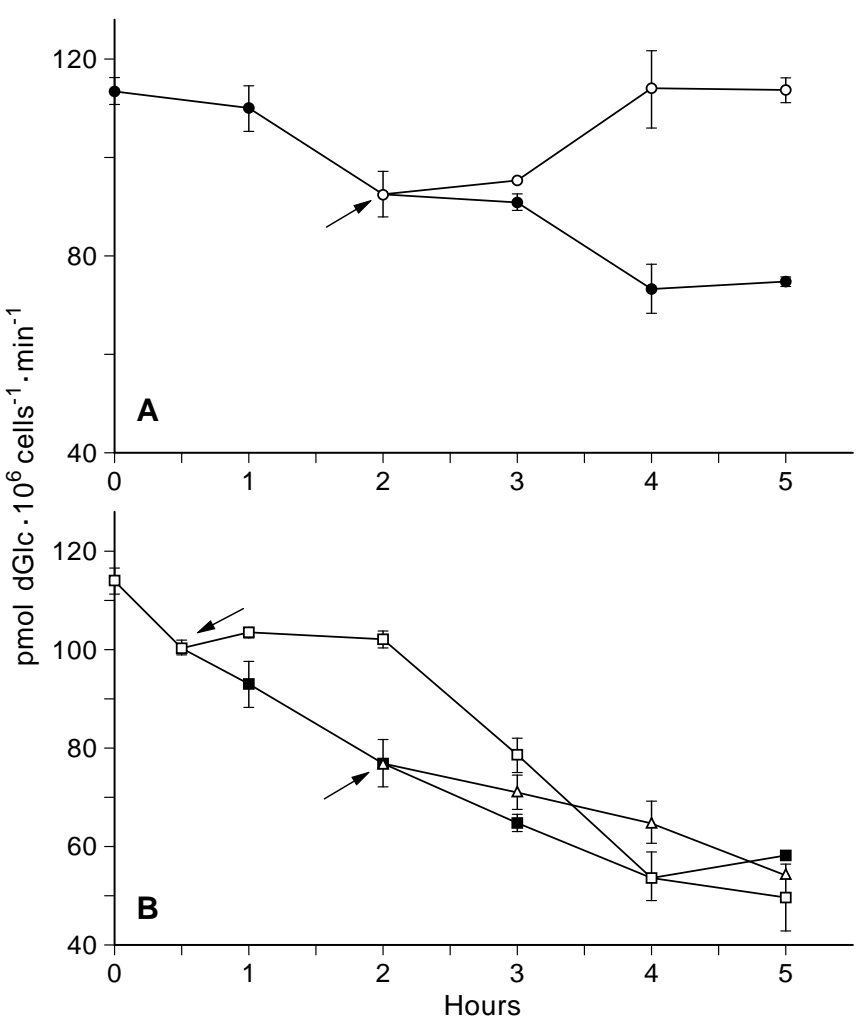

Fig. 3A , B. dG Ic-induced prolonged downregulation of hexose transport. (A) L 8 myocytes were preincubated for $20 \mathrm{~h}$ with DMEM supplemented with $2.0 \mathrm{mmol} / \mathrm{l}$ glucose, then washed and incubated for $5 \mathrm{~h}$ with fresh DMEM containing $20.0 \mathrm{mmol} / \mathrm{l}$ glucose (O). At $2 \mathrm{~h}$, some of the cultures were transferred to $2.0 \mathrm{mmol} / \mathrm{l}$ glucose $(\bigcirc)$. (B) A fter preincubation with $2.0 \mathrm{mmol} / \mathrm{l}$ glucose the cells received $2.0 \mathrm{mmol} / \mathrm{l} \mathrm{dG} \mathrm{Ic}$ (D). In some of the culture plates, the medium was changed to $2.0 \mathrm{mmol} / \mathrm{l}$ glucose after $30 \mathrm{~min}(\square)$ or $2 \mathrm{~h}(\triangle)$. The uptake of $\left[{ }^{3} \mathrm{H}\right] \mathrm{dG}$ Ic was measured at the indicated times. A rrows indicate the time the medium was changed to $2.0 \mathrm{mmol} / \mathrm{l}$ glucose. $M$ ean \pm SE $M, n=3$

$5 \mathrm{~h}$. Figure 4 shows a curvilinear relationship between the cellular content of dG Ic-6-P and the magnitude of the reduction in hexose uptake. A ccumulation of $\sim 5$ and $\sim 20 \mathrm{nmol}$ dG Ic-6-P $/ 10^{6}$ cells was sufficient to induce half-maximal and maximal downregulatory effects, respectively.

F urther evidence for the role of intracellular dG Ic$6-P$ in initiating and maintaining downregulation of 


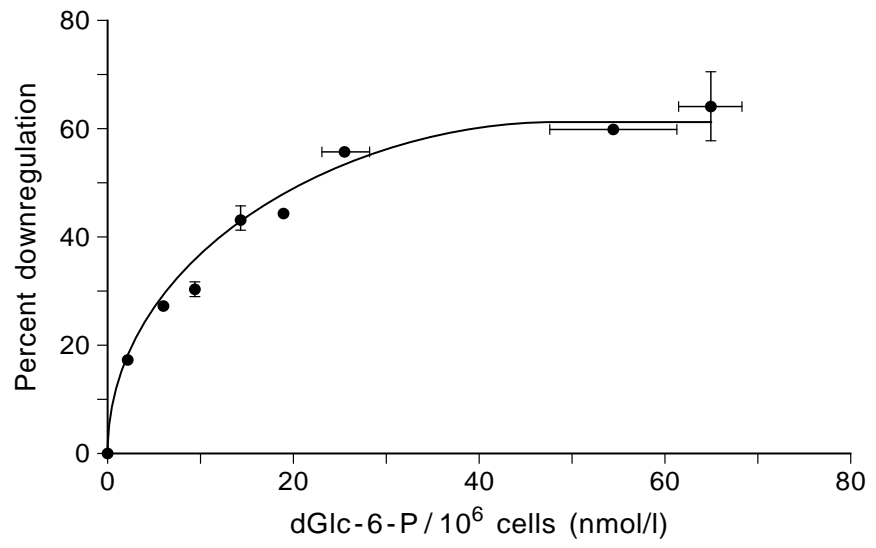

Fig. 4. R elationship between intracellular dG Ic-6-P and downregulation of hexose transport. $L 8$ myocytes were preincubated for $20 \mathrm{~h}$ with DMEM containing $2.0 \mathrm{mmol} / \mathrm{l}$ glucose. The cells were washed and received fresh medium with $2.0 \mathrm{mmol} / / \mathrm{dG} / \mathrm{c}$. Intracellular dG Ic-6-P and $\left[{ }^{3} \mathrm{H}\right] \mathrm{dG}$ Ic uptake were measured at 20 and $40 \mathrm{~min}$ and at 1.0, 1.5, 2.0, 2.5 and $5.0 \mathrm{~h}$. U ptake results are expressed as percentage of the downregulation from time zero $\left(93.9 \pm 4.7 \mathrm{pmol} \mathrm{dGIc} \cdot 10^{6} \mathrm{cells}^{-1}\right.$. $\left.\min ^{-1}\right)$. M ean $\pm S E M, n=3$. H orizontal and vertical bars give the SEM of dG Ic-6-P accumulation and of downregulation of transport, respectively

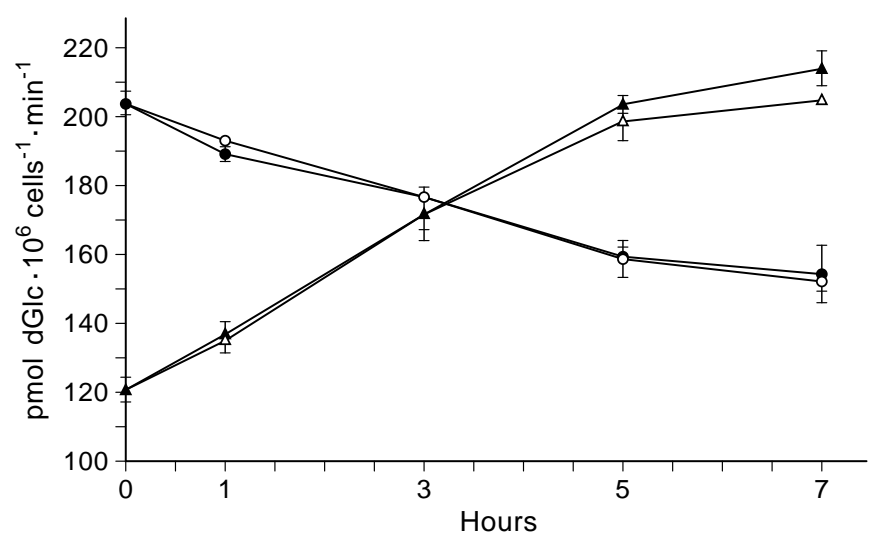

Fig. 5. E ffect of cell permeabilisation on up- and downregulation of hexose transport. L 8 myocytes were preincubated for $20 \mathrm{~h}$ with D M E M containing 2.0 or $20.0 \mathrm{mmol} / \mathrm{l}$ glucose. Some of the plates were then washed and permeabilised (open symbols), while the rest were washed in a saponin-free permeabilization buffer (closed symbols). Cells that were preincubated with $2.0 \mathrm{mmol} / \mathrm{l}$ glucose received $20.0 \mathrm{mmol} / \mathrm{l}$ glucose (O. $\bigcirc$ ); those preincubated with $20.0 \mathrm{mmol} / \mathrm{l}$ glucose received $2.0 \mathrm{mmol} / \mathrm{l}$ glucose $(\boldsymbol{\Delta}, \Delta)$. The uptake of $\left[{ }^{3} \mathrm{H}\right] \mathrm{dG}$ Ic was measured at the indicated times. M ean \pm SE M , $n=3$

hexose transport comes from premeabilisation experiments. Figure 5 shows control experiments in which cell permeabilisation did not interfere with the course of up- or downregulation of hexose transport. Therefore, this method was suitable to study the effect of dG Ic-6-P efflux from dG Ic-treated cells. Figure $6 \mathrm{~A}$ shows a rapid $80 \%$ depletion of cell-associated dG Ic-6-P following permeabilisation. Control cells that were treated in parallel with saponin-free
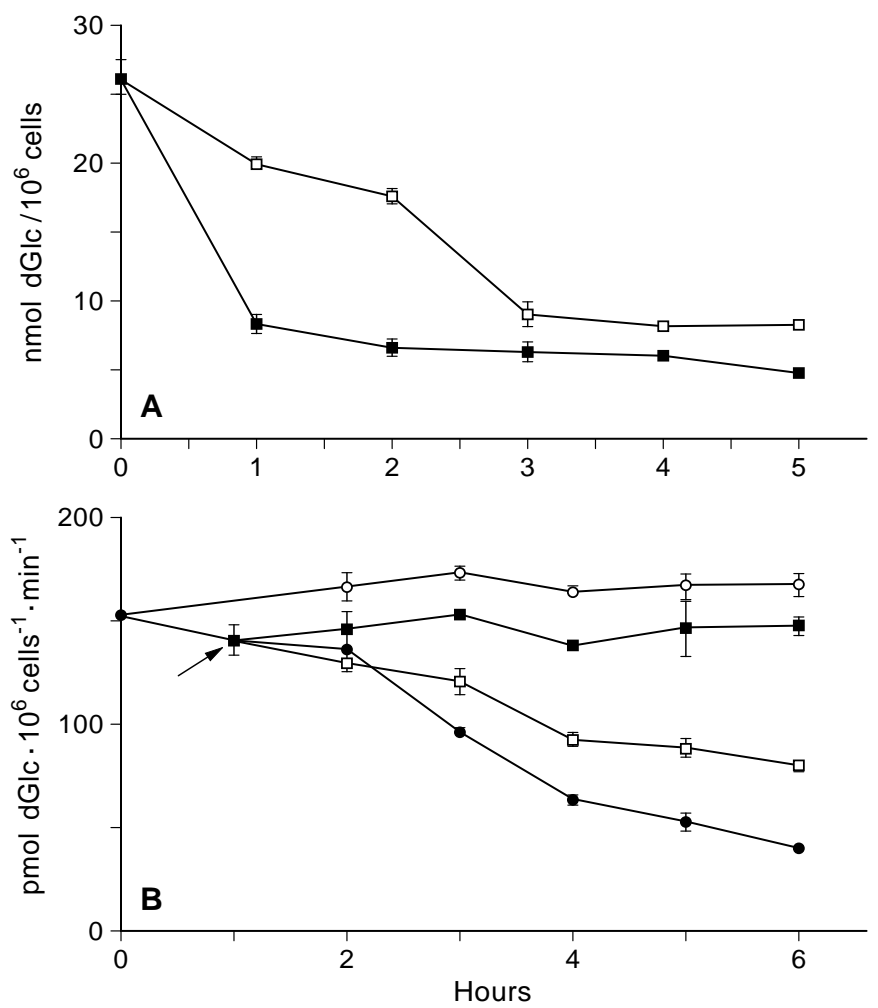

Fig. 6A , B . E ffect of cell permeabilisation on intracellular content of dG Ic-6-P and dG Ic-induced downregulation of hexose transport. (A) L 8 myocytes preincubated in D MEM containing $2.0 \mathrm{mmol} / /$ glucose for $20 \mathrm{~h}$ were washed and incubated with $2.0 \mathrm{mmol} / \mathrm{l} \mathrm{dG} \mathrm{Ic}$ and $2.5 \mu \mathrm{Ci}\left[{ }^{3} \mathrm{H}\right.$ ]dG Ic for $1 \mathrm{~h}$. The plates were then treated with permeabilisation buffer without ( $\square$ ) or with ( $\square$ ) saponin. The intracellular content of labelled $\mathrm{dG}$ Ic was determined at the indicated times, following washes and solubilisation of the cells. (B) L 8 myocytes were preincubated in D ME M containing $2.0 \mathrm{mmol} / \mathrm{l}$ glucose for $20 \mathrm{~h}$. Some cells were then washed and received DMEM containing $2.0 \mathrm{mmol} / \mathrm{l}$ glucose $(O)$. O ther cells were washed and incubated with $2.0 \mathrm{mmol} / \mathrm{l} \mathrm{dG} \mathrm{Ic} \mathrm{(O).} \mathrm{A} \mathrm{fter} 1 \mathrm{~h}$ some of these cells were treated with permeabilisation buffer without $(\square)$ or with ( $\square$ ) saponin, and incubated further with D M E M containing $2.0 \mathrm{mmol} / \mathrm{l}$ glucose. The uptake of $\left[{ }^{3} \mathrm{H}\right] \mathrm{dG}$ Ic was measured at the indicated times. $M$ ean $\pm S E M, n=3$

buffer lost the phosphorylated metabolite at a slower rate, probably due to the activity of intracellular phosphatase(s). The data depicted in Figure 6B show that the depletion of dGIc-6-P following treatment with $2.0 \mathrm{mmol} / \mathrm{d} \mathrm{dG} \mathrm{Ic} \mathrm{and} \mathrm{permeabilisation} \mathrm{reversed}$ the downregulatory response to $\mathrm{dG} / \mathrm{c}$, and returned the rate of hexose transport to the level typical for incubation with low glucose. Moreover, control cells, pretreated with $2.0 \mathrm{mmol} / \mathrm{l} \mathrm{dGIc}$ and then treated with saponin-free buffer, continued the downregulation process.

E ffect of dG Ic on myocyte ATP content. Phosphorylation of $d G$ Ic consumes A TP which by itself could affect cellular functions as hexose transport. Figure 7 shows that myocyte ATP was indeed reduced 


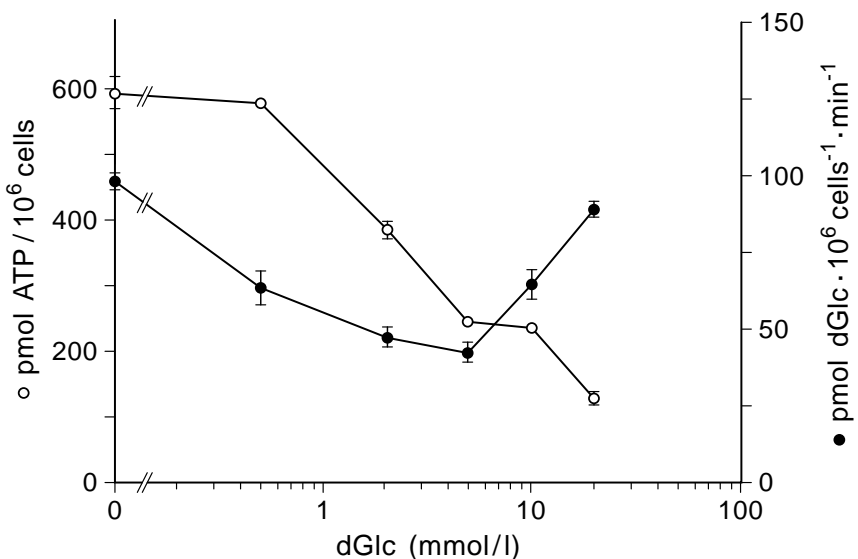

Fig. 7. E ffect of $d G$ Ic on A TP content. M yocytes were preincubated for $20 \mathrm{~h}$ with D M E M containing $2.0 \mathrm{mmol} / \mathrm{l}$ glucose, washed and incubated for additional $5 \mathrm{~h}$ with fresh medium containing increasing dG Ic concentrations. A t the end of the incubation the cells were taken for $\left[{ }^{3} \mathrm{H}\right] \mathrm{dG}$ Ic uptake assay (O) and total cellular A TP determination $(O)$ as described under $E x-$ perimental Procedures. M ean \pm SE $M, n=3$

under the experimental conditions described for Figure 2; however, there was no clear correlation between reduction in cell A TP and the degree of transport downregulation. Thus, a significant downregulatory effect was observed with $0.5 \mathrm{mmol} / \mathrm{l} \mathrm{dG}$ Ic without significant changes in A TP. Severe A TP depletion induced by $20.0 \mathrm{mmol} / \mathrm{l} \mathrm{dG}$ Ic was not accompanied by a downregulatory response; on the contrary, the cells responded by increasing the transport. To investigate the role of A TP depletion alone we studied the effect of the uncoupler DNP. Table 3 shows that $0.25 \mathrm{mmol} / / \mathrm{DNP}$ abolished the downregulation of the uptake induced by $20.0 \mathrm{mmol} / \mathrm{l}$ glucose, and augmented the upregulation induced by $2.0 \mathrm{mmol} / \mathrm{l}$ glucose. In parallel, the A TP content was reduced by 24.9 and $28.1 \%$. Thus, reduction in cell ATP content is associated with upregulation rather than downregulation of hexose transport. These results therefore negate a role for A TP depletion in dG Ic-induced downregulation of hexose uptake. Furthermore, pronounced A TP depletion ( $>70 \%$ ) overrode the downregulatory effect of $d G I c$, as observed in myocytes incubated with $20.0 \mathrm{mmol} / \mathrm{l} \mathrm{dG} \mathrm{Ic}$ for $5 \mathrm{~h}$ (Figs. 2 and 5). Therefore, the observed dG Ic-induced reduction of hexose transport may be an underestimate of the true downregulatory effect of the analogue, partially opposed by the upregulatory effect of A TP depletion.

K inetic analysis of dGIc-induced downregulation of hexose transport. Table 4 summarises the kinetic parameters derived from experiments in which uptake data of up- and downregulated myocytes following treatments with $2.0 \mathrm{mmol} / \mathrm{l} \mathrm{dGIc}$ were analysed according to L ineweaver and B urk [19]. dG Ic treatment reduced the maximal velocity $\left(\mathrm{V}_{\max }\right)$ of the transport system without significant effect on the affinity $\left(\mathrm{K}_{\mathrm{m}}\right)$ for $d G$ Ic.

Effect of dGIc on plasma membrane GLUT1 in $L 8$ myocytes. To investigate further the nature of the dGIc effect we determined the plasma membrane content of GLUT1, the major glucose transporter of these cells, using cell surface biotinylation in intact cells. Figure 8 shows the results of a representative experiment: surface GLUT1 content in cells incubated for $20 \mathrm{~h}$ at $20.0 \mathrm{mmol} / \mathrm{l}$ glucose was $45 \%$ of that observed in cells incubated with $2.0 \mathrm{mmol} / \mathrm{l}$ glucose; also hexose uptake was reduced by $\sim 50 \%$. When myocytes preincubated at 2.0 $\mathrm{mmol} / / \mathrm{g}$ glucose were treated with $2.0 \mathrm{mmol} / \mathrm{l} \mathrm{dG} \mathrm{Ic}$ or $20.0 \mathrm{mmol} / \mathrm{l}$ glucose for additional $5 \mathrm{~h}$, cell surface GLUT 1 was decreased by 72 and $70 \%$, respectively, while the rate of hexose transport was reduced by 73 and $67 \%$. The total cell content of G LUT 1, determined by Western blotting of crude membranes (containing both plasma- and internal membranes), was not affected by the above treatments (data not shown).

Effect of dGIc on GLUT1 mRNA in L 8 myocytes. $\mathrm{H}$ igh glucose concentrations not only downregulate hexose transport, but also reduce the content of GLUT1 mRNA in L 8 myocytes [5]. Figure 9 shows

Table 3. E ffect of D N P on hexose uptake and A TP content

\begin{tabular}{|c|c|c|c|c|}
\hline \multirow[t]{2}{*}{ Treatment } & \multicolumn{2}{|l|}{ dG Ic uptake } & \multicolumn{2}{|l|}{ A TP content } \\
\hline & $\mathrm{pmol} \cdot 10^{6} \mathrm{cells}^{-1} \cdot \mathrm{min}^{-1}$ & $(\%)$ & $\mathrm{pmol} / 10^{6}$ cells & $(\%)$ \\
\hline $\begin{array}{l}2.0 \mathrm{mmol} / \mathrm{l} \text { glucose }(20 \mathrm{~h}) \\
\rightarrow 20.0 \mathrm{mmol} / \mathrm{l} \text { glucose } \\
\rightarrow 20.0 \mathrm{mmol} / \mathrm{g} \text { glucose + D NP }\end{array}$ & $\begin{array}{c}150.1 \pm 4.7 \\
99.4 \pm 6.5^{\mathrm{a}} \\
139.3 \pm 10.5^{\mathrm{b}}\end{array}$ & $\begin{array}{r}100 \\
66.2 \pm 4.3 \\
92.8 \pm 7.0\end{array}$ & $\begin{array}{l}475.0 \pm 24.0 \\
439.9 \pm 29.3 \\
356.6 \pm 5.8^{a, b}\end{array}$ & $\begin{array}{r}100 \\
92.6 \pm 6.2 \\
75.1 \pm 1.2\end{array}$ \\
\hline $\begin{array}{l}20.0 \mathrm{mmol} / / \text { glucose }(20 \mathrm{~h}) \\
\rightarrow 2.0 \mathrm{mmol} / / \mathrm{glucose} \\
\rightarrow 2.0 \mathrm{mmol} / / \mathrm{glucose}+\mathrm{DNP}\end{array}$ & $\begin{array}{l}80.2 \pm 6.2 \\
136.6 \pm 1.9^{a} \\
160.6 \pm 1.0^{a, b}\end{array}$ & $\begin{array}{l}100 \\
170.3 \pm 2.4 \\
200.2 \pm 1.2\end{array}$ & $\begin{array}{l}440.2 \pm 30.2 \\
473.6 \pm 24.4 \\
316.6 \pm 3.6^{a, b}\end{array}$ & $\begin{array}{r}100 \\
107.6 \pm 5.5 \\
71.9 \pm 0.2\end{array}$ \\
\hline
\end{tabular}

L 8 myocytes were incubated for $20 \mathrm{~h}$ with 2.0 or $20.0 \mathrm{mmol} / \mathrm{l}$ glucose, then washed and incubated for additional $5 \mathrm{~h}$ with DMEM containing the opposite glucose concentration with or without $0.25 \mathrm{mmol} / \mathrm{D} \mathrm{NP}$, and taken for $\left[{ }^{3} \mathrm{H}\right] \mathrm{dG}$ Ic uptake assay and determination of A TP content as described in M ethods. M ean \pm SEM $(n=3)$. a $p<0.05$ compared to control; ${ }^{b}$ significantly different from the value obtained for the incubation with $20.0 \mathrm{mmol} / \mathrm{l}$ glucose 
Table 4. K inetic analysis of the effect of $d G$ Ic

\begin{tabular}{lll}
\hline Treatment & $\begin{array}{l}\mathrm{K}_{\mathrm{m}} \\
(\mathrm{mmol} / \mathrm{l})\end{array}$ & $\begin{array}{l}\mathrm{V}_{\max } \\
\left(\mathrm{nmol} \mathrm{dG} \mathrm{Ic} \cdot 10^{6}\right. \\
\left.\mathrm{cells}^{-1} \cdot \mathrm{min}^{-1}\right)\end{array}$ \\
\hline $2.0 \mathrm{mmol} / /$ glucose & $1.68 \pm 0.12$ & $4.16 \pm 0.43$ \\
$2.0 \mathrm{mmol} / \mathrm{g}$ glucose $\rightarrow$ dG Ic & $1.88 \pm 0.09$ & $2.26 \pm 0.19^{\mathrm{a}}$ \\
$20.0 \mathrm{mmol} / \mathrm{g}$ glucose & $1.50 \pm 0.21$ & $2.31 \pm 0.47^{\mathrm{a}}$ \\
$20.0 \mathrm{mmol} / \mathrm{l}$ glucose $\rightarrow$ dG Ic & $1.71 \pm 0.59$ & $1.95 \pm 0.85^{\mathrm{a}}$
\end{tabular}

L 8 myocytes were incubated with DMEM supplemented with 2.0 or $20.0 \mathrm{mmol} / \mathrm{l}$ glucose for $20 \mathrm{~h}$. The cells were then washed and received fresh DMEM containing the same glucose concentration or $2.0 \mathrm{mmol} / \mathrm{l} \mathrm{dG} \mathrm{Ic}$, and incubated for additional $5 \mathrm{~h}$. The kinetic parameters of dG Ic uptake were calculated from dose-response experiments according to Lineweaver and Burk [19]. Mean $\pm S E M, n=3$ to 6 experiments. ${ }^{a} p<0.05$, significantly different from the $2.0 \mathrm{mmol} / /$ glucose control

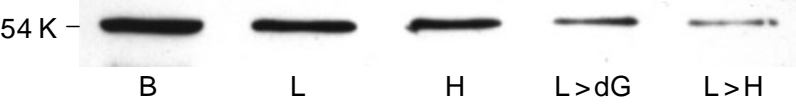

Fig. 8. E ffect of dG Ic on myocyte plasma membrane G LUT 1 . $\mathrm{L} 8$ myocytes were incubated for $20 \mathrm{~h}$ in $2.0 \mathrm{mmol} / \mathrm{l}(\mathrm{L})$ or $20 \mathrm{mmol} / \mathrm{l}$ glucose $(\mathrm{H})$. The cultures then received fresh medium containing the same glucose concentrations, and some cultures preincubated with $2 \mathrm{mmol} / /$ glucose received fresh medium containing either $20 \mathrm{mmol} / \mathrm{l}$ glucose $(\mathrm{L}>\mathrm{H})$ or $2.0 \mathrm{mmol} / \mathrm{l} \mathrm{dG} \mathrm{Ic} \mathrm{(} \mathrm{C}>\mathrm{dG}$ ). A fter additional $5 \mathrm{~h}$ incubation the cells were biotinylated and processed as described under Experimental Procedures. Samples ( $5 \mu \mathrm{g} / \mathrm{lane}$ ) of biotinylated proteins were resolved electrophoretically and GLUT1 protein was visualized with anti-G LUT1 ( $\mathrm{N}$-terminus) polyclonal antibody. B denotes control of crude membranes prepared from rat brain

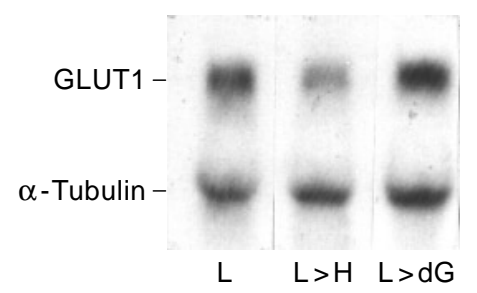

Fig. 9. Effect of dGIc on myocyte GLUT-1 mRNA. L 8 myocytes were preincubated with $2.0 \mathrm{mmol} / /$ glucose for $20 \mathrm{~h}(\mathrm{~L})$. The cells were then washed and incubated for additional $5 \mathrm{~h}$ with fresh medium containing $20.0 \mathrm{mmol} / \mathrm{l}$ glucose $(\mathrm{L}>\mathrm{H})$ or $2.0 \mathrm{mmol} / \mathrm{d} \mathrm{dG} \mathrm{Ic} \mathrm{(} \mathrm{c}>\mathrm{dG}$ ). Total R NA was extracted from the cells, separated electrophoretically and hybridised with rat G LUT 1 and $\alpha_{1}$ tubulin probes as described under $E$ xperimental Procedures

that pre-exposure of the cells to $2.0 \mathrm{mmol} / \mathrm{l}$ glucose for $20 \mathrm{~h}$ and incubation at $20.0 \mathrm{mmol} / \mathrm{l}$ glucose for additional $5 \mathrm{~h}$ reduced the GLUT1 mRNA content by $54 \%$. In contrast, the mR NA level following $5 \mathrm{~h}$ exposure of the cells to $2.0 \mathrm{mmol} / \mathrm{l}$ dG Ic was $137 \%$ of that observed in control cells.

\section{Discussion}

R esults from our $[1-5,20,21]$ and other laboratories [9] over recent years convincingly demonstrated that extracellular glucose is an important feed-back regulator of its transport through the cell membrane. G lucose transport in skeletal muscle is the limiting step for hexose metabolism in toto, therefore regulation of this step by glucose can be expected to result in the modulation of all aspects of cellular glucose metabolism. Glucose concentrations of the magnitude often seen in diabetic patients are capable of substantially reducing the muscle glucose transport and utilization $[3,8]$. Indeed, hyperglycaemia per se has been proposed to be one of the causes of reduced peripheral glucose disposal in diabetic patients [10-12, 22]. However, the mechanism by which glucose effects this action is not clear.

Extracellular glucose produces a signal which affects the subcellular distribution of glucose transporters, thus influencing their content in the plasma membrane of the myocyte $[1,6,23]$. The intracellular signal(s) involved in this autoregulatory response is not known. L -glucose was ineffective [2]; evidently interaction with the glucose transporter is necessary. It was therefore deemed suitable to investigate whether transport alone, transport and phosphorylation at position 6, or further metabolism are necessary to elicit the downregulatory signal of glucose. The glucose analogue dG IC is transported into the cells by the hexose transport system, interacts with hexokinase, but is not metabolized beyond the dGIc-6-P step. This study shows that low dG Ic concentrations can mimic the downregulatory action of high glucose levels.

D eoxyglucose-6-P, like glucose-6- $P$, can inhibit the hexokinase activity. However, the fact that the rate of hexose uptake, measured with both $\left[{ }^{3} \mathrm{H}\right] \mathrm{dG} \mathrm{Ic}$ and $\left[{ }^{3} \mathrm{H}\right] \mathrm{M}$ eG Ic, was similarly reduced by high glucose or dG Ic treatments indicates that the transport mechanism and not the hexokinase reaction in $L 8$ myocytes is the target of the autoregulatory signal. GLUT1 is the main glucose transporter of $L 8$ myocytes $[1,5]$. Direct measurement of GLUT1 content in the plasma membrane of the myocytes demonstrated that dGIc, like high glucose concentrations, reduced the density of transporters. The cell surface biotinylation technique used to measure the cell surface content of glucose transporters was chosen because it is simple and not complicated with low yields and crosscontamination of enriched-membrane preparations obtained by the alternative method of subcellular fractionation. The data obtained by this procedure showed a good correlation between the content of GLUT1 in the plasma membrane of the myocytes and the reduction in hexose transport capacity, induced by $2.0 \mathrm{mmol} / \mathrm{l} \mathrm{dG} / \mathrm{c}$ or $20.0 \mathrm{mmol} / \mathrm{l}$ glucose. The total content of GLUT1 transporters was not changed during relatively short exposures to dG Ic or 
high glucose concentrations (data not shown), indicating that the steady state level of the transporter was not affected.

D eoxyglucose reduces the cell A TP content. H owever, we could not relate this action to the effect of the analogue on hexose transport. Indeed, other procedures that reduce A TP (hypoxia, anoxia, uncouplers of oxidative phosphorylation) were shown to augment hexose transport and induce translocation of glucose transporters to the plasma membrane in a variety of cells and tissues [24]. A Iso in the present study the uncoupler DNP, while lowering the cell A TP level, stimulated the hexose transport in L 8 myocytes. Therefore, the effect of low concentrations of $\mathrm{dG}$ lc on the hexose transporter is independent of its A TP consuming effect.

The effect of dG Ic seems to be mediated by its major metabolite, dG Ic-6-P. A short exposure to low dG Ic concentrations was sufficient to initiate and drive to completion the downregulation of hexose transport in myocytes. The time required for half maximal downregulatory effect of dG Ic was inversely related to the time of exposure (data not shown). A curvilinear relationship existed between intracellular dG Ic-6-P concentration and the degree of downregulation of hexose transport. Furthermore, permeabilisation of the dG Ic-treated cells, resulting in loss of more than $80 \%$ of cell dG Ic-6-P, reversed the downregulatory process. In control cells dG Ic-6-P disappeared at a slow rate, probably as a result of phosphatase activity; however, the intracellular dG Ic-6-P concentration remained significantly high to sustain the downregulatory mechanism. Control experiments indicated that the mild saponin treatment had no significant effect on either up- or downregulation of hexose transport. This confirms a previous study showing that this method did not compromise cell integrity and function [17]. O ur findings verify the study by Naftalin and Rist [25] in which preloading rat thymocytes with dG Ic (1-10 mmol/l) decreased the rate of M eG Ic uptake. Similar results observed by Foley and $\mathrm{H}$ uecksteadt [26] in adipocytes were ascribed to the effect of increased intracellular hexose6-P. Wheeler [27], on the other hand, found no similar effects of glucose-6-P on hexose transport into liposomes from reconstituted adipocyte membrane proteins. G lucose-6-P had no effect on hexose transport activity also in plasma membrane vesicles prepared from skeletal muscles [28]. Taken together, we conclude that the effect of hexose-6-P on glucose transporters requires intact cells, indicating that a mechanism of transporter redistribution in the cells is the target of this glucose metabolite.

The proposed effect of hexose-6-P in initiating downregulation of glucose transport is strongly supported by studies in which the content of glucose-6-P was determined in skeletal muscle biopsies of diabetic patients. Y ki-Järvinen et al. [29] reported that the content of glucose-6-P was 2.3 times higher in biopsies of vastus lateralis muscles of diabetic compared to non-diabetic subjects. Young et al. [30] found an inverse correlation between muscle glucose-6-P and glucose disposal, and suggested that the main control over carbohydrate disposal in muscle occurred after glucose-6-P, as increased insulin-stimulated glucose disposal was associated with a reduction in muscle glucose- $6-P$. The pool of glucose- $6-P$ is determined by the sum of the rates of glycogen synthesis and glycolysis. R educed glycogen synthesis in skeletal muscles of diabetic patients may augment the glucose-6-P levels [31, 32]. R othman et al. [33], on the other hand, using ${ }^{31} \mathrm{P}$ nuclear magnetic resonance spectroscopy, found lower glucose-6-P levels in muscles of diabetic patients compared to control subjects under hyperglycaemic-hyperinsulinaemic clamps. In this context it is important to note the early studies of Sims and L andau [34] and D ully et al. [35] which suggested distinctive insulin-responsive and insulin non-responsive pools of glucose-6-P in skeletal muscles. O ur results also indicate that $\sim 20 \%$ of cellassociated dG IC-6-P could not be mobilised following saponin treatment. Considering these early studies and the present observations it seems important to determine the steady state levels and compartmentalisation of glucose-6-P pools and their relation to glucose transport and utilization in skeletal muscles of normal and diabetic patients. In our study, relatively high intracellular levels of $\mathrm{dG}$ IC-6-P were required to induce maximal downregulation of hexose transport and reduction of cell surface GLUT1. This may be due to a lower affinity of the signalling system to dG Ic-6-P. This correlates well with a three-orders of magnitude lower affinity of this compound to glucose-6-P dehydrogenase compared to that of the natural substrate, glucose-6-P [36, 37]. Thus, dG Ic-6-P may mimic the effects of glucose-6-P, albeit at higher concentrations.

The role ascribed here to phosphorylated glucose or dG Ic in cellular signalling and transduction, coupled to subcellular localization of G LUT1, is not unusual. For instance, mannose-6-P is a high affinity ligand for the insulin-like growth factor II/mannose-6$P$ receptor and the cation-dependent mannose-6- $P$ receptor. B oth receptors regulate the transport of lysosomal enzymes from the trans-G olgi to a prelysosomal compartment and the cell surface [38-40]. Further work will have the challenge of identifying the structures that interact with hexose-6-P and control the cellular location of glucose transporters.

$G$ lucose has been shown to regulate the expression and steady-state level of GLUT1 mRNA in several types of cells [9]. We have shown before that glucose reduces the content of GLUT1 mRNA in L8 myocytes in a dose- and time-dependent manner [5]. The observation that, unlike glucose, dG Ic had no downregulatory effect on GLUT1MRNA level in 
myocytes suggests that glucose operates two distinct regulatory systems in muscle. O ne, shared by $d G I c$, affects the subcellular distribution of GLUT1 and consequently the rate of hexose uptake, while the second reduces the content of G LUT1 mR NA, probably at the transcription level [5]. The latter is apparently induced by a signal generated downstream of the hexokinase reaction during glucose metabolism.

A cknowledgements. We thank M s. A . D avarashvili for excellent technical help. This study was supported by grants from The I srael $\mathrm{M}$ inistry of $\mathrm{H}$ ealth, and a donation by $\mathrm{M} \mathrm{r}$. and $\mathrm{M} \mathrm{rs}$. Jack Sasson. E frat Wertheimer was a Picciotto D octoral Fellow.

\section{References}

1. G reco-Perotto $R$, Wertheimer $E$, Jeanrenaud $B$, Cerasi $E$, Sasson S (1992) G lucose regulates its transport in L 8 myocytes by modulating cellular trafficking of the transporter GLUT-1. Biochem J 286: 157-163

2. Sasson S, Cerasi E (1986) Substrate regulation of glucose transport system in rat skeletal muscle: characterization and kinetic analysis in isolated soleus muscle and skeletal muscle cells in culture. J B iol Chem 261: 16827-16833

3. Sasson S, E delson D, Cerasi E (1987) In vitro autoregulation of glucose utilization in rat soleus muscle. Diabetes 36: 1041-1046

4. Wertheimer E, Sasson S, Cerasi E (1990) Regulation of hexose transport in L 8 myocytes by glucose: possible sites of interaction. J Cell Physiol 143: 330-336

5. Wertheimer E, Sasson S, Cerasi E, Ben-Neriah Y (1991) The ubiquitous glucose transporter GLUT-1 belongs to the glucose-regulated family of stress-inducible proteins. Proc Natl A cad Sci (U SA ) 88: 2525-2529

6. Walker PS, Ramlal T, Sarabia V, et al. (1990) Glucose transport activity in $\mathrm{L} 6$ muscle cells is regulated by the coordinate control of subcellular glucose transporter distribution, biosynthesis, and mR NA transcription. J Biol Chem 265: 1516-1523

7. E I-K abbi I M , R oser S, Pollet RJ, Cushman SW, Wilson CM (1994) Regulation of GLUT1 glucose transporter in cultured myocytes: total number and subcellular distribution as determined by photoaffinity labeling. B iochem J 30: 3540

8. Z ierath J R, G aluska D, N olte L A , Thorne A, SmedegaardK ristensen J, Wallberg-H enriksson $H$ (1994) E ffects of glycaemia on glucose transport in isolated skeletal muscle from patients with NIDDM : in vitro reversal of muscular insulin resistance. D iabetologia 37: 270-277

9. K lip A , T sakiridis T, M arette A , O rtiz PA (1994) R egulation of expression of glucose transporters by glucose: a review of studies in vivo and in cell cultures. FA SE B J 8:43-53

10. Cerasi E, Glaser B, Del-Rio G, Sasson S, Della-Casa L (1989) The clinical significance of insulin resistance in NIDDM : studies with continuous subcutaneous insulin infusion. In: A Iberti K G M M , M azze R (eds) Frontiers of diabetes research: current trends in non-insulin-dependent diabetes mellitus. E Isevier Science Publishers, N ew Y ork, pp 309-320

11. R ossetti L, Giaccari A, D eFronzo R A (1990) Glucose toxicity. D iabetes Care 13: 610-630

12. Y ki-Järvinen H (1990) A cute and chronic effects of hyperglycaemia on glucose metabolism. D iabetologia 33: 579-585
13. Tsuboi K K , Petricciani J C (1975) Concentrative accumulation (active transport) of 2-deoxy-D-glucose in primate fibroblasts. Biochem B iophys R es Commun 62: 587-593

14. Shetty M , L oeb J N, Vikstrom K, B eigi FI (1993) R apid activation of G lut-1 glucose transporter following inhibition of oxidative phosphorylation in Clone 9 cells. J B iol Chem 268: 17225-17232

15. L evy-Toledano R, Caro R, H indman L H, Taylor SI (1993) Streptavidin blotting: a sensitive technique to study cell surface proteins: application to investigate autophosphorylation and endocytosis of biotin-labeled insulin receptors. Endocrinology 133: 1803-1808

16. L aemmli U K (1970) Cleavage of structural proteins during the assembly of the head of bacteriophage T4. Nature 227: 680-685

17. Johnson JA, G ray M O, Karliner J S, Chen C-H, MochlyRosen D (1996) A n improved permeabilisation protocol for the introduction of peptides into cardiac myocytes: application to protein kinase $C$ research. Circulation $\mathrm{R}$ es (in press)

18. L udin A , B altscheffsky M (1978) D etermination of creatine kinase isoenzymes in human serum by an immunological method using purified firefly luciferase. In: D eL uca M (ed) Methods in enzymology, Vol. 57. A cademic Press, New York, pp 56-72

19. Segal HS (1975) E nzyme kinetics: behavior and analysis of rapid equilibrium and steady-state enzyme systems. John Wiley $\&$ Sons, N ew Y ork

20. K aiser N, Sasson S, Peener EP, et al. (1993) D ifferential regulation of glucose transport and transporters by glucose in vascular endothelial and smooth muscle cells. Diabetes 42: 80-89

21. Sasson S, G orowits N, J oost J H , K ing G L, Cerasi E , K aiser $\mathrm{N}$ (1996) R egulation by metformin of hexose transport system in vascular endothelial and smooth muscle cells. B r J Pharmacol 117: 1318-1324

22. E fendic S, L uft R, Wajngot A (1984) A spects of the pathogenesis of type 2 diabetes. $E$ ndocrine $R$ ev 5: 395-410

23. Koivisto U-M, Martinez-Valdez $H$, Bilan PJ, Burdett $E$, $R$ amlal T, K lip A (1991) Differential regulation of G LUT1 and G L U T-4 glucose transport systems by glucose and insulin in L 6 muscle cells in culture. J Biol Chem 266: 26152621

24. Wheeler TJ (1988) Translocation of glucose transporters in response to anoxia in heart. J Biol Chem 263: 1944719454

25. N aftalin RJ , R ist RJ (1990) E ffects of phorbol, dexamethasone and starvation on 3-0 -methyl-D-glucose by rat thymocytes. Biochem J 265: 251-259

26. Foley J E, H uecksteadt TP (1984) G lucose-6-phosphate effects on deoxyglucose, glucose and methylglucose transport in rat adipocytes. B iochim B iophys A cta 805: 313-316

27. Wheeler TJ (1989) E ffects of three proposed inhibitors of adipocyte glucose transporter on the reconstituted transporter. Biochim Biophys A cta 979: 331-340

28. K ristiansen S, Wojtaszewski J F, Juel C, Richter E A (1994) E ffect of glucose-6-phosphate and $\mathrm{pH}$ on glucose transport in skeletal muscle plasma membrane giant vesicles. A cta Physiol Scan 150: 227-233

29. Y ki-Järvinen H, Sahlin K, R en J M , Koivisto VA (1990) L ocalization of rate-limiting defect for glucose disposal in skeletal muscle of insulin-resistant type I diabetic patients. Diabetes 39: 157-167

30. Y oung A A, B ogardus C, Stone K, M ott D M (1988) Insulin response of components of whole-body and muscle carbohydrate metabolism in humans. A m J Physiol 254: E 231E 236 
31. Thorburn A W, G umbiner B, B ulacan F, B rechtel G, H enry $R R$ (1991) Multiple defects in muscle glycogen synthase activity contribute to reduced glycogen synthesis in non-insulin dependent diabetes mellitus. J Clin I nvest 87: 489-495

32. Shulman GI, Rothman DL, Jue T, Stein RA, Defronzo RA, Shulman R G (1990) Q uantitation of muscle glycogen synthesis in normal subjects and subjects with noninsulindependent diabetes by $13 \mathrm{C}$ nuclear magnetic resonance spectroscopy. N E ngl J M ed 322: 223-228

33. R othmann D L, Shulman R G, Shulman GI (1992) 31P nuclear magnetic resonance measurements of muscle glucose-6-phosphate. E vidence for reduced insulin-dependent muscle glucose transport or phosphorylation activity in non-insulin-dependent diabetes mellitus. J Clin Invest 89: 1069-1075

34. Sims EA , L andau BR (1966) Insulin responsive and insulin nonresponsive pools of glucose-6-phosphate in diaphragmatic muscle. Fed Proc 25: 835-839

35. Dully CC, B ocek RM, Beaty CH (1969) Presence of two or more glucose-6-phosphate pools in voluntary skeletal muscle and their sensitivity to insulin. Endocrinology 84 : 855-860

36. Sasson S, O ron R, Cerasi E (1993) E nzymatic assay of 2-deoxyglucose 6-phosphate for assessing hexose uptake rates in cultured cells. A nal Biochem 215: 309-311

37. M anchester J K, Chi M, Carter M - Y, Pusateri M E , M CD ougal D B , L owry OH (1990) M easurement of 2-deoxyglucose and 2-deoxyglucose-6-phosphate in tissues. A nal B iochem 185: 118-124

38. Kornfeld S, M ellman I (1989) The pathogenesis of Iysosomes. A nnu Rev Cell Biol 5: 483-525

39. Stein M , Zijderhand-B leekemolen J E, G euze H, H asilik A , von Figura K (1987) M r 46,000 mannose 6-phosphate specific receptor: its role in targeting of lysosomal enzymes. E M BO J 6: 2677-2681

40. Szebenyi G, Rotwein P (1991) Differential regulation of mannose-6-phosphate receptors and their ligands during the myogenic development of C2 cells. J Biol Chem 266: 5534-5539 